\title{
Gambaran nitrit urin pada pasien tuberkulosis paru dewasa di RSUP Prof. Dr. R. D. Kandou Manado
}

\author{
${ }^{1}$ Lusye A. H. Berhandus \\ ${ }^{2}$ Arthur E. Mongan \\ ${ }^{2}$ Mayer F. Wowor
}

\author{
${ }^{1}$ Kandidat Skripsi Fakultas Kedokteran Universitas Sam Ratulangi Manado \\ ${ }^{2}$ Bagian Patologi Klinik Fakultas Kedokteran Universitas Sam Ratulangi Manado \\ Email: Lusyeberhandus31@gmail.com
}

\begin{abstract}
Tuberculosis (TB) is an infectious disease caused by Mycobacterium Tuberculosis. Pulmonary TB influence nutritional status because the course of the disease that affects immune system and caused immunodeficiency which makes TB patient prone to infection including urinary tract infection. The most common diagnostic method is chemical urinalysis using urine dipstick especially nitrite. Nitrite urine examination can be used to find bacteria in urine. In normal urine, nitrite is usually absent, but nitrate in urine will be reduced by the bacteria that have reductase enzyme and change to nitrite. This study was aimed to obtain the urine nitrite profile in adult pulmonary tuberculosis patients at Prof. Dr. R. D. Kandou Hospital Manado. This was a descriptive study with a cross sectoional design to obtain data of nitrite in urinalysis of pulmonary tuberculosis patients from October to November 2016 at Prof. Dr. R. D. Kandou Hospital Manado. Sampels were urine of all pulmonary tuberculosis patients that met the inclusion criteria. The results showed that all 30 patients' urine samples did not contain nitrite. Conclusion: The profile of urine of 30 pulmonary tuberculosis patients showed absence of nitrite.
\end{abstract}

Keywords: pulmonary tuberculosis, urinalysis, nitrite

\begin{abstract}
Abstrak: Tuberkulosis (TB) adalah penyakit akibat infeksi bakteri Mycobacterium tuberculosis. TB paru dapat mempengaruhi status gizi penderita karena proses perjalanan penyakitnya yang mempengaruhi daya tahan tubuh menyebabkan immunodefisiensi sehingga rentan terkena berbagai penyakit infeksi diantaranya infeksi saluran kemih. Metode paling umum pada urinalisis adalah uji kimia dengan menggunakan dipstick urin terutama nitrit. Pemeriksaan nitrit urin dapat digunakan untuk mengetahui ada tidaknya bakteriuria. Pada urin normal tidak terdapat nitrit, namun nitrat yang terdapat pada urin akan mengalami reduksi oleh bakteri yang mempunyai enzim reduktase menjadi nitrit. Penelitian ini bertujuan untuk mengetahui gambaran nitrit urin pada pasien tuberkulosis paru dewasa di RSUP Prof. Dr. R. D. Kandou Manado. Jenis penelitian ialah deskriptif dengan desain potong lintang. Sampel penelitian ialah urin sewaktu dari semua pasien tuberkulosis paru yang memenuhi kriteria inklusi. Dari hasil urinalisis nitrit urin yang dilakukan terhadap 30 pasien yang terdiagnosis penyakit tuberkulosis paru dewasa, seluruhnya (30 pasien) didapatkan hasil nitrit negatif. Simpulan : Dari 30 pasien yang diperiksa nitrit urin didapatkan seluruhnya hasil nitrit negatif.
\end{abstract}

Kata kunci : tuberkulosis paru, urinalisis, nitrit

Tuberkulosis (TB) adalah penyakit akibat infeksi bakteri Mycobacterium tuberculosis yang merupakan masalah kesehatan masyarakat didunia. Tuberkulosis paru merupakan bentuk yang paling sering dijumpai yaitu sekitar $80 \%$ dari semua 
penderita. ${ }^{1}$ Menurut laporan tahun 2015 terdapat sekitar 10,4 juta kasus tuberkulosis baru, 5.9 juta kasus pada pria, 3.5 juta kasus pada wanita, dan 1 juta kasus pada anak-anak. ${ }^{2}$ TB paru dapat mempengaruhi status gizi penderita karena proses perjalanan penyakitnya yang memengaruhi daya tahan tubuh. Penderita TB yang mengalami kekurangan gizi akan mengakibatkan produksi antibodi dan limfosit terhambat, sehingga proses penyembuhan akan terhambat pula, kekurangan nutrisi menyebabkan immunedefisiensi secara umum untuk berbagai penyakit infeksi diantaranya infeksi saluran kemih. $^{3}$

Urinalisis adalah salah satu pemeriksaan laboratorium yang penting untuk menegakkan berbagai diagnosis. ${ }^{4} \mathrm{Uji}$ urinalisis terdiri dari uji makroskopik, uji kimia, dan uji mikroskopik. Saat ini metode paling umum pada urinalisis adalah uji kimia dengan menggunakan dipstick urin. Uji ini dapat menunjukkan rentang kandungan kimia yang ada pada urin, salah satunya adalah nitrit. ${ }^{5}$ Pemeriksaan nitrit urin dapat digunakan untuk mengetahui ada tidaknya bakteriuria. Nitrit urin merupakan hasil metabolisme bakteri golongan enterobacteriaceae. Hampir semua golongan enterobacteriaceae dapat mereduksi nitrat. Pada urin normal tidak terdapat nitrit, namun nitrat yang terdapat pada urin akan mengalami reduksi oleh bakteri yang mempunyai enzim reduktase menjadi nitrit. Perubahan nitrat menjadi nitrit memerlukan waktu sekurangnya 4 jam. ${ }^{6-8}$

Penelitian ini bertujuan untuk mengetahui gambaran nitrit urin pada pasien tuberkulosis paru dewasa di RSUP Prof. Dr. R. D. Kandou Manado.

\section{METODE PENELITIAN}

Jenis penelitian ini ialah deskriptif dengan desain potong lintang. Penelitian ini dilaksanakan di poliklinik paru dan instalasi rawat inap bagian penyakit dalam RSUP. Prof. Dr. R. D. Kandou Manado selama bulan oktober sampai november 2016. Sampel penelitian ini adalah sampel urin sewaktu dari semua pasien tuberkulosis paru dewasa dalam kurun waktu dan kriteria yang telah ditentukan dengan cara non-probability sampling jenis consecutive sampling.

\section{HASIL PENELITIAN DAN BAHASAN}

Berdasarkan hasil penelitian yang telah dilakukan dengan cara mengambil sampel urin pasien tuberkulosis paru dewasa di Poliklinik Paru dan rawat inap bagian Ilmu Penyakit Dalam RSUP Prof. Dr. R. D. Kandou Manado diperoleh sebanyak 30 pasien yang terdiri dari 6 pasien rawat inap dan 24 pasien rawat jalan. Kemudian dilakukan pemeriksaan sampel urin di Laboratorium Pro-Kita Manado.

Pada penelitian ini didapatkan kelompok usia 36-45 tahun yang terbanyak mengidap penyakit tuberkulosis paru dengan 8 orang pasien atau $36,6 \%$. Hal ini tidak jauh berbeda dari Pedoman Nasional Pengendalian tuberkulosis, sekitar $75 \%$ pasien TB adalah kelompok usia yang paling produktif 15-50 tahun. ${ }^{9}$ Amin et al. ${ }^{10}$ mengungkapkan bahwa di Indonesia penderita tuberkulosis paru pada usia produktif 20-49 tahun. Umur produktif sangat berbahaya terhadap tingkat penularan karena pasien mudah berinteraksi dengan orang lain, mobilitas yang tinggi dan memungkinkan untuk menular ke orang lain serta lingkungan sekitar tempat tinggal. ${ }^{11}$ Hal ini menunjukkan penyakit tuberkulosis paru meningkat pada usia dewasa atau usia produktif.

Tabel 1. Distribusi pasien tuberkulosis paru menurut usia

\begin{tabular}{ccc}
\hline Usia & Jumlah & \% \\
\hline 18-25 Tahun & 4 & $13,3 \%$ \\
26-35 Tahun & 4 & $13,3 \%$ \\
36-45 Tahun & 8 & $26,7 \%$ \\
46-55 Tahun & 6 & $20,0 \%$ \\
56-65 Tahun & 6 & $20,0 \%$ \\
66-75 Tahun & 2 & $6,7 \%$ \\
Total & 30 & $100,0 \%$ \\
\hline
\end{tabular}

Pada penelitian ini didapatkan jenis 
kelamin laki-laki lebih banyak dibandingkan perempuan. Hasil yang sama juga didapatkan dari $\mathrm{WHO}^{2}$ yang menyebutkan bahwa laki-laki sebanyak $56 \%$ lebih banyak menderita tuberkulosis dari perempuan sebanyak $34 \%$. Pada lakilaki penyakit TB Paru lebih tinggi dibandingkan pada perempun karena kebiasaan laki-laki yang sering merokok dan mengkonsumsi minuman beralkohol yang dapat menurunkan sistem pertahanan tubuh sehingga wajar bila perokok dan peminum alkohol sering disebut sebagai agen dari penyakit TB Paru. ${ }^{10}$ Hal ini menunjukkan jenis kelamin laki-laki lebih banyak dibandingkan dengan perempuan pada penyakit tuberkulosis paru.

Tabel 2. Distribusi pasien tuberkulosis paru menurut jenis kelamin

\begin{tabular}{lcc}
\hline Jenis Kelamin & Jumlah & $\mathbf{\%}$ \\
\hline Laki-laki & 20 & $66,7 \%$ \\
Perempuan & 10 & $33,3 \%$ \\
$\quad$ Total & 30 & $100,0 \%$ \\
\hline
\end{tabular}

Tabel 3 memperlihatkan yang terbanyak ialah pasien tuberkulosis paru tanpa penyakit penyerta. Hal ini berbeda dengan penelitian dari Reviono et al. yaitu diabetes melitus (DM) merupakan penyakit penyerta terbesar tuberkulosis paru sebanyak 51,2\%. Pada DM terjadi hiperglikemia yang dapat menyebabkan menurunnya aktivitas sel fagosit untuk membunuh mikroorganisme dalam leukosit. $^{12}$ Hal ini berbeda dengan hasil penelitian ini dimana penyakit penyerta DM sebanyak $16,7 \%$.

Tabel 3. Distribusi pasein tuberkulosis paru menurut penyakit penyerta

\begin{tabular}{lcc}
\hline Penyakit Penyerta & Jumlah & \% \\
\hline Diabetes mellitus & 5 & $16,7 \%$ \\
Hipertensi & 4 & $13,3 \%$ \\
Asam urat & 5 & $16,7 \%$ \\
Gangguan ginjal & 6 & $20,0 \%$ \\
Tidak ada & 17 & $56,7 \%$ \\
\hline
\end{tabular}

Pada penelitian ini dari seluruh 32 pasien tuberkulosis paru yang terdiri 24 pasien (80\%) rawat jalan dan 6 pasien $(20 \%)$ rawat inap memberikan hasil urinalisis nitrit negatif. Hasil positif dari tes nitrit merupakan indikasi yang dapat diandalkan untuk menandakan adanya bakteriuria signifikan. Tes nitrit mempunyai sensitivitas yang tinggi pada bakteriuri yang disebabkan oleh bakteri gram negatif terutama escherchi coli dan golongan enterobacter. ${ }^{6,13}$ Penyakit tuberkulosis paru dewasa merupakan penyakit yang disebabkan oleh infeksi bakteri gram positif yaitu Mycobacterium tuberculosis. ${ }^{1}$ Berdasarkan penelitian ini pada penyakit tuberkulosis paru dewasa dengan bakteri Gram positif memberikan hasil urinalisis nitrit negatif.

Table 4. Hasil nitrit urin berdasarkan pasien tuberculosis

\begin{tabular}{ccc}
\hline Hasil & Jumlah & \% \\
\hline Positif & 0 & $0 \%$ \\
Negatif & 30 & $100 \%$ \\
Total & 30 & $100 \%$ \\
\hline
\end{tabular}

Dapat dilihat dari tabel 5 yang terbanyak ialah pasien tuberkulosis paru dengan tanpa penyakit penyerta sebanyak 17 orang atau 56,7\% memberikan hasil urinalisis nitrit negatif. Hal ini berbeda dengan penelitian dari Reviono et al. mengungkapkan diabetes mellitus merupakan penyakit penyerta terbesar tuberkulosis paru sebanyak 51,2\%. ${ }^{12}$ Pasien diabetes mellitus beresiko mengalami komplikasi kronik diantaranya adalah infeksi. Infeksi pada pasien diabetes umumnya terlokalisasi di saluran kemih. Berdasarkan hasil penelitian ini pada pemeriksaan urinalisis nitrit, penyakit tuberkulosis tanpa penyakit penyerta, diabetes melitus, hipertensi, asam urat, gangguan ginjal memberikan hasil urinalisis nitrit negatif.

Pada penelitian ini dapat dilihat, jenis pengobatan kategori 1 merupakan jenis pengobatan terbanyak pada penelitian ini sebanyak 24 orang pasien atau $80 \%$. Hasil ini sama dengan data penelitian yang didapat oleh Simamora et al $^{14}$ pengobatan 
OAT kategori 1 menempati peringkat pertama $86,4 \%$. Berdasarkan hal ini hasil urinalisis nitrit dengan jenis pengobatan kategori 1 dan kategori 2 memberikan hasil urinalisis nitrit negative (Tabel 6).

Tabel 5. Distribusi hasil pemeriksaan urinalisis nitrit berdasarkan penyakit penyerta

\begin{tabular}{ccc}
\hline \multirow{2}{*}{$\begin{array}{c}\text { Penyakit } \\
\text { Penyerta }\end{array}$} & $\begin{array}{c}\text { Hasil } \\
\text { Positif }\end{array}$ & $\begin{array}{c}\text { Hasil } \\
\text { Negatif }\end{array}$ \\
\cline { 2 - 3 } & Jumlah(\%) & Jumlah(\%) \\
\hline Diabetes mellitus & $0(0 \%)$ & $5(16,7 \%)$ \\
Hipertensi & $0(0 \%)$ & $4(13,3 \%)$ \\
Asam urat & $0(0 \%)$ & $5(16,7 \%)$ \\
Gangguan ginjal & $0(0 \%)$ & $6(20,0 \%)$ \\
Tanpa penyerta & $0(0 \%)$ & $17(56,7 \%)$ \\
\hline
\end{tabular}

Tabel 6. Distribusi hasil pemeriksaan urinalisis nitrit berdasarkan jenis pengobatan

\begin{tabular}{ccc}
\hline \multirow{2}{*}{$\begin{array}{c}\text { Jenis } \\
\text { Pengobatan }\end{array}$} & $\begin{array}{c}\text { Hasil } \\
\text { Positif }\end{array}$ & $\begin{array}{c}\text { Hasil } \\
\text { Negatif }\end{array}$ \\
\cline { 2 - 3 } & Jumlah (\%) & Jumlah (\%) \\
\hline Kategori 1 & $0(0 \%)$ & $24(80,0 \%)$ \\
Kategori 2 & $0(0 \%)$ & $6(20,0 \%)$ \\
Total & $0(0 \%)$ & $30(100 \%)$ \\
\hline
\end{tabular}

Pada penelitian ini jenis kasus terbanyak pada pasien penyakit tuberkulosis ialah jenis kasus baru sebanyak 13 pasien $(43,3 \%)$ memberikan hasil urinalisis nitrit negatif (Tabel 7).

Tabel 7. Distribusi hasil pemeriksaan urinalisis nitrit berdasarkan jenis kasus TBC

\begin{tabular}{ccc}
\hline \multirow{2}{*}{ Jenis Kasus } & $\begin{array}{c}\text { Hasil } \\
\text { Positif }\end{array}$ & $\begin{array}{c}\text { Hasil } \\
\text { Negatif }\end{array}$ \\
\cline { 2 - 3 } & Jumlah (\%) & Jumlah $(\%)$ \\
\hline Baru & $0(0 \%)$ & $13(43,3 \%)$ \\
Putus Obat & $0(0 \%)$ & $8(26,7 \%)$ \\
Gagal Terapi & $0(0 \%)$ & $1(3.3 \%)$ \\
Relaps & $0(0 \%)$ & $8(26,7 \%)$ \\
\hline Total & $0(0 \%)$ & $30(100,0 \%)$ \\
\hline
\end{tabular}

Data ini tidak jauh berbeda dari hasil penelitian yang didapat oleh Simamora et $\mathrm{al}^{14}$ dari semua jenis kasus tuberkulosis yang ada jenis kasus baru menempati peringkat pertama sebanyak $86,4 \%$. Kasus baru merupakan penderita yang belum pernah mendapat pengobatan dengan OAT atau sudah pernah menelan OAT kurang dari satu bulan (30 dosis harian). ${ }^{1}$ Berdasarkan urinalisis nitrit pasien tuberkulosis paru dengan jenis kasus baru, putus obat, gagal terapi, dan relaps memberikan hasil urinalisis nitrit negatif.

Pada penelitian ini pasien dengan lama pengobatan terbanyak kurang dari 1 bulan sebanyak 12 orang pasien atau 40,0\% memberikan hasil urinalisis nitrit negatif. Hal ini berkaitan dengan jenis kasus dan jenis pengobatan pada penelitian ini. Jenis kasus terbanyak yaitu jenis kasus baru dan kategori 1 merupakan jenis pengobatan terbanyak pada penelitian ini. Secara keseluruhan urinalisis nitrit pasien tuberkulosis paru dengan lama pengobatan memberikan hasil urinalisis nitrit negative (Tabel 8).

Tabel 8. Distribusi hasil pemeriksaan urinalisis nitrit berdasarkan lama pengobatan

\begin{tabular}{lcc}
\hline $\begin{array}{c}\text { Lama } \\
\text { pengobatan }\end{array}$ & $\begin{array}{c}\text { Hasil } \\
\text { Positif }\end{array}$ & $\begin{array}{c}\text { Hasil } \\
\text { Negatif }\end{array}$ \\
\cline { 2 - 3 } & $\begin{array}{l}\text { Jumlah } \\
(\%)\end{array}$ & Jumlah (\%) \\
\hline < 1 Bulan & $0(0 \%)$ & $12(40,0 \%)$ \\
1-2 Bulan & $0(0 \%)$ & $7(23,3 \%)$ \\
2-4 Bulan & $0(0 \%)$ & $5(16,7 \%)$ \\
4-6 Bulan & $0(0 \%)$ & $1(3.3 \%)$ \\
6 Bulan & $0(0 \%)$ & $5(16,7 \%)$ \\
$\quad$ Total & $0(0 \%)$ & $32(100 \%)$ \\
\hline
\end{tabular}

Secara keseluruhan, dalam penelitian ini dari 30 pasien tuberkulosis paru dewasa menghasilkan pemeriksaan urin nitrit negatif. Penyakit tuberkulosis paru merupakan penyakit yang disebabkan oleh infeksi bakteri Gram positif (Mycobacterium tuberculosis). ${ }^{1}$ Berdasarkan teori, kehadiran nitrit dalam urin merupakan indikator dari penyakit infeksi saluran kemih dan nitrit hadir dengan bakteri gram negatif yang dapat menghasilkan enzim nitrat reduktase. ${ }^{13,15}$ 
Nitrat yang terdapat dalam urin akan mengalami reduksi oleh bakteri yang mempunyai enzim reduktase menjadi nitrit. ${ }^{16}$ Sehingga hasil positif dari pemeriksaan urin nitrit menujukkan adanya aktivitas bakteri yang menghasilkan enzim reduktase, sebaliknya Pemeriksaan urin nitrit dengan hasil negatif dapat mengekslusi adanya infeksi bakteri. ${ }^{6}$

Hasil positif palsu dari pemeriksaan nitrit urin bisa didapatkan bila urin terkontaminasi, carik celup terpapar udara lebih dari 1 minggu, atau pasien menggunakan obat fenazopiridin. ${ }^{6}$ Hasil negatif palsu dari pemeriksaan nitrit urin juga bisa didapatkan. Menurut teori hasil negatif palsu dapat disebabkan oleh adanya kuman penyebab bakteriuri asimtomatis yang tidak menghasilkan nitrit, atau pada kuman yang melakukan metabolisme nitrat menjadi amonia dengan cepat sehingga nitrit hanya sebentar saja berada dalam urin. Semakin lama urin berada dalam kandung kemih maka semakin besar kemungkinan hasil positif didapatkan, karena bakteri penyebab bakteriuri memerlukan waktu 4 jam untuk mereduksi nitrat menjadi nitrit. Hasil negatif palsu dapat juga dapat disebabkan karena ada peningkatan berat jenis, peningkatan urobilinogen, $\mathrm{pH}, 6,0$, serta pasien mengkonsumsi vitamin $\mathrm{C}^{6}$

Penjelasan tentang hubungan tuberkulosis paru dewasa dan pemeriksaan nitrit urin masih kurang lazim dilaporkan atau diteliti. Pada penelitian ini, menggunakan sampel urin sewaktu atau random, seharusnya seperti yang ada pada teori urin terbaik untuk urinalisis nitrit mengunakan urin pada pagi hari atau urin yang diambil pertama kali saat bangun tidur, dengan asumsi urin harus berada minimal 4 jam didalam kandung kemih untuk mencegah terjadinya hasil urinalisis nitrit negatif.

\section{SIMPULAN}

Berdasarkan hasil penelitian yang dilakukan di RSUP Prof. Dr. R. D. Kandou Manado dapat disimpulkan bahwa dari 30 pasien tuberkulosis paru yang diperiksa nitrit urin didapatkan hasil nitrit negatif.

\section{SARAN}

Jumlah sampel penelitian diperbanyak untuk menghindari terjadinya bias dalam penelitian. Perlu penerapan metode analitik sehingga bisa mengetahui hubungan sebab akibat antara kedua variabel tuberkulosis paru dan nitrit. Perlu informasi lebih lengkap tentang data pasien atau subjek penelitian. Perlu pengambilan urin pagi hari untuk mencegah terjadinya hasil urinalisis nitrit negatif palsu.

\section{DAFTAR PUSTAKA}

1. PDPI. Pedoman Diagnosis dan Penatalaksanaan Tuberkulosis di Indonesia. 2006.

2. World Health Organization. Global Tuberculosis Report 2016. Switzerland: World Health Organization. 2016.

3. Rahardja FM. Nutrisi Pada Tuberkulosis Paru Dengan Malnutrisi. Damianus Journal of Medicine. 2015;14(1);8088.

4. Indranila KS, Lukitaning P. Akurasi Pemeriksaan Carik Celup pada Urinalisis Proteinuria dan Glukosuria dibandingkan dengan Metoda Standard. Molucca Medica. 2012:05(1):19-23.

5. Izzah A, Ginardi H, Saikhu A. Pendekatan Algoritma Heuristik dan Neural Network Untuk Screening Test Pada Urinalysis. Jurnal Cybermatika. 2013:1(2):6.

6. Mundt L A, Shanahan K. Chemical Analysis of Urine. Graff's Textbook of Routine Urinalysis and Body Fluids. $2^{\text {nd }}$ ed. Philadelphia: Lippincott Williams \& Wilkins; 2011. p. 49-50.

7. Lie JT. Evaluation of a nitrite tes kit (stattest) for the detection of significant bacteriuria. Australia. J Clin. Path. 1968;21;443-444.

8. Abirami K, Tiwari SC. Urinalysis in Clinical Practice. J Indian Acad Clin Med. 2001;2:39-50.

9. Kementerian Kesehatan RI Direktorat Jenderal Pengendalian Penyakit dan Penyehatan Lingkungan. Pedoman Nasional Pengendalian 
Tuberkulosis. Jakarta: Kementerian Kesehatan2014.

10.Amin Z, Bahar A. Tuberkulosis Paru. Dalam: setiati S, Alwi I, Sudoyo AW, Simadibrata KM, Setiyohadi B, Syam AF, editor. Buku Ajar Ilmu Penyakit Dalam. Edisi ke-6. Jakarta: InternaPublishing; 2014: h. 863-7.

11.Sihombing $H$, Sembiring $H$, Amir $Z$, Bintang Y.M, Sinaga. Pola Resistensi Primer pada Penderita TB Paru Kategori I di RSUPH. Adam Malik, Medan. J Respir Indo. 2012; 32:138-45.

12.Sianturi R. Analisis Faktor yang Berhubungan dengan Kekambuhan TB Paru. UJPH. 2014;3(1).

13.James GP, Paul KL, Fuller JB. Urinary nitrite and urinary- tract infection. Am J Clin Pathol. 1978;70:671-
67.

14.Simamora V, Tjitrosantoso, Wiyono WI. Evaluasi Penggunaan Obat Anti Tuberkulosis pada Pasien Tuberkulosis Paru di Instalasi Rawat Inap RSUP. Prof. Dr. R. D. Kandou Manado Periode Januari - Desember 2010. [Skripsi]. Manado: Universitas Sam Ratulangi;2011.

15.Majid F, Buba F. The Predictive and Discriminant Values of Urine Nitrites in Urinary Tracrt Infection. Department of Medicine. BR. 2010; 21(3):297-299.

16.Powell HR, Mccredie DA,Ritchie MA. Urinary Nitrite In Symptomatic And Asymptomatic Urinary Infection. Australia. Archives of Disease in Childhood. 1987;63;138-140. 